\title{
Performance of ultra low temperature district heating systems with utility plant and booster heat pumps
}

Ommen, Torben Schmidt; Thorsen, Jan Eric; Markussen, Wiebke Brix; Elmegaard, Brian

Published in:

Energy

Link to article, DOI:

10.1016/j.energy.2017.05.165

Publication date:

2017

Document Version

Peer reviewed version

Link back to DTU Orbit

Citation (APA):

Ommen, T. S., Thorsen, J. E., Markussen, W. B., \& Elmegaard, B. (2017). Performance of ultra low temperature district heating systems with utility plant and booster heat pumps. Energy, 137, 544-555.

https://doi.org/10.1016/j.energy.2017.05.165

\section{General rights}

Copyright and moral rights for the publications made accessible in the public portal are retained by the authors and/or other copyright owners and it is a condition of accessing publications that users recognise and abide by the legal requirements associated with these rights.

- Users may download and print one copy of any publication from the public portal for the purpose of private study or research.

- You may not further distribute the material or use it for any profit-making activity or commercial gain

- You may freely distribute the URL identifying the publication in the public portal 


\section{Accepted Manuscript}

Performance of ultra low temperature district heating systems with utility plant and booster heat pumps

Torben Ommen, Jan Eric Thorsen, Wiebke Brix Markussen, Brian Elmegaard

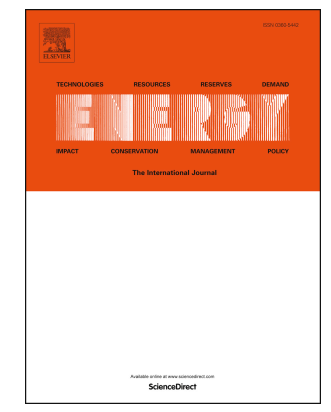

PII:

S0360-5442(17)30954-4

DOI:

10.1016/j.energy.2017.05.165

Reference: EGY 10973

To appear in: Energy

Received Date: 31 October 2016

Revised Date: 20 April 2017

Accepted Date: 28 May 2017

Please cite this article as: Ommen T, Thorsen JE, Markussen WB, Elmegaard B, Performance of ultra low temperature district heating systems with utility plant and booster heat pumps, Energy (2017), doi: 10.1016/j.energy.2017.05.165.

This is a PDF file of an unedited manuscript that has been accepted for publication. As a service to our customers we are providing this early version of the manuscript. The manuscript will undergo copyediting, typesetting, and review of the resulting proof before it is published in its final form. Please note that during the production process errors may be discovered which could affect the content, and all legal disclaimers that apply to the journal pertain. 


\title{
Performance of ultra low temperature district heating systems with utility plant and booster heat pumps
}

\author{
Torben Ommen ${ }^{\mathrm{a}, *}$, Jan Eric Thorsen ${ }^{\mathrm{b}}$, Wiebke Brix Markussen ${ }^{\mathrm{a}}$, Brian Elmegaard ${ }^{\mathrm{a}}$ \\ ${ }^{a}$ Technical University of Denmark, Kgs. Lyngby, Denmark \\ ${ }^{b}$ Danfoss Heating Segment, Nordborg, Denmark
}

\begin{abstract}
The optimal integration of booster heat pumps in ultra low temperature district heating (ULTDH) was investigated and compared to the performance of low temperature district heating. Two possible heat production technologies for the $\mathrm{DH}$ networks were analysed, namely extraction combined heat and power (CHP) and central heat pumps (HPs). The analysis focussed on the characteristic heat demands of newly build multi-story buildings and the results were based on the ratio of the individual demands compared to the total. It was found that the optimal return temperature was dependent on the forward temperature and the heat consumption profile. For reference conditions, the optimal return of ULTDH varies between $21{ }^{\circ} \mathrm{C}$ and $27{ }^{\circ} \mathrm{C}$. When using a central HP to supply the DH system, the resulting coefficient of system performance (COSP) was in the range of 3.9 (-) to 4.7 (-) for equipment with realistic component efficiencies and effectiveness, when including the relevant parameters such as DH system pressure and heat losses. By using ULTDH with booster HPs, performance improvements of $12 \%$ for the reference calculations case were found, if the system was supplied by central HPs. Opposite results were found for extraction CHP, were ULTDH with booster HPs resulted in decreasing COSP of $20 \%$.
\end{abstract}

Keywords: 4gDH, Ultra low temperature district heating, Heat pumps, Combined heat and power

\section{Introduction}

In areas with temperate climate and high population density, district heating (DH) has proven to be economically competitive, and to show significant energy savings compared to individual heating solutions, e.g., for Denmark [1]. Both energy and economic savings may also be obtained in urban areas with warmer 5 climates [2]. However, with decreasing space heating (SH) heat demands in newly built dwellings and multifamily buildings, DH is challenged by other technologies for cost efficient supply of residential heat services $[3,4]$. This is the case as heat losses and investment costs of distribution networks become increasingly important in both socio-economic and private economic analyses, with a decrease in the total amount of delivered energy. On the other hand, economy of scale decreases production costs of the utility plants.

Each of the above factors should consequently be carefully considered in the analysis of new developments or expansion of existing systems. To add to this, DH may further improve cost effectiveness of other sectors, as it is a key component in the Smart Energy Systems approach [5] stating that the "Smart Energy Systems concept is essential for $100 \%$ renewable energy systems to harvest storage synergies and exploit low value heat sources".

A reduction in DH supply temperatures is proposed in order to increase district heating efficiency, as well as to allow more heat sources to be easily integrated in the heat network [6]. Lowering DH supply

\footnotetext{
* Corresponding author

Email addresses: tsom@mek.dtu.dk (Torben Ommen), jet@Danfoss.com (Jan Eric Thorsen), wb@mek.dtu.dk (Wiebke Brix Markussen), be@mek.dtu.dk (Brian Elmegaard)
} 


\section{Nomenclature}

\begin{tabular}{|c|c|c|c|}
\hline$C$ & constant & in & inlet \\
\hline$f$ & ratio or fraction, - & out & outlet \\
\hline$k$ & opening degree, - & $\operatorname{sink}$ & sink reservoir \\
\hline$\dot{m}$ & massflow, kg/s & source & source reservoir \\
\hline$p$ & pressure, $\mathrm{Pa}$ & tur & turbine \\
\hline$T$ & temperature, ${ }^{\circ} \mathrm{C}$ & & \\
\hline$\dot{V}$ & Volumeflow, $\mathrm{m}^{3} / \mathrm{s}$ & Abbreviations & \\
\hline & & $\mathrm{CHP}$ & Combined Heat and Power \\
\hline Greek symbols & & $\mathrm{COP}$ & Coefficient Of Performance \\
\hline$\alpha$ & flow characteristic & COSP & Coefficient Of System Performance \\
\hline$\beta$ & power loss factor for heat extraction & $\mathrm{DH}$ & District Heating \\
\hline$\Delta$ & difference & DHW & Domestic Hot Water \\
\hline$\rho$ & density, $\mathrm{kg} / \mathrm{m}^{3}$ & DHWC & Domestic Hot Water Circulation \\
\hline & & Gen & Generator \\
\hline Subscripts & & LTDH & Low Temperature District Heating \\
\hline cond & condensation & $\mathrm{HP}(\mathrm{s})$ & Heat Pump(s) \\
\hline $\operatorname{dim}$ & dimensioning & $\mathrm{SH}$ & Space Heating \\
\hline evap & evaporation & ULTDH & Ultra Low Temperature District Heating \\
\hline elec & electric & & \\
\hline
\end{tabular}

temperatures to e.g., $60{ }^{\circ} \mathrm{C}$ [7] may in many cases be an acceptable solution for both existing and new buildings [8].

Especially three advantages are worth mentioning for systems with lower temperatures in the network: improvements in performance of renewable heating technologies, either by direct utilization (e.g., solar thermal collectors) or by use of heat pumps (HPs), the possibility for decreased heat losses as well as improvements in performance of existing centralised utility plants. On the other hand, the low temperature (LT) DH has lower temperature difference between supply and return lines, and is thus subject to increased investment and/or pump work due to the larger volume flow rate for a fixed heat delivery.

Opposite to the LTDH, the design of ultra low temperature (ULT) DH systems calls for changed layout and requirements to the end-user installations [9], as the temperature of the DH forward stream does not satisfy demand temperatures or bacteria prevention measures [10].

The topic of ULTDH has received attention in a number of recent publications. The technology has been proposed for two quite different energy scenarios:

1 Expansion of existing DH networks, where troublesome capacity constraints are addressed, which is achieved by connecting ULTDH consumers at remote positions by utilizing the return flow $[11,12]$. This may be done without interfering with consumers requiring $\mathrm{DH}$ at traditional temperature levels.

2 The design of new or updated systems with better performance of utility units according to the production temperatures and lower losses in DH network [7, 13].

For the first item, it was shown in Elmegaard et al. [11], that the highest exergetic efficiency, and lowest cost for consumers, were obtained for LTDH systems. On the other hand, ULTDH offers an increase in energy efficiency. For the case studies Graz and Güssing, where both LTDH and ULTDH are considered, similar results are found for operation costs [12]. Further, for the case study of Güssing, the energy efficiency is increased for the ULTDH solution, compared to LTDH.

For the second item, Ommen et al. [7] suggest that the the optimum in terms of costs and emmissions is at the transition temperature betweeen LTDH and ULTDH, but recommends the use of LTDH, as booster HPs would not be required in each dwelling. In Østergaard and Andersen [13] the performance of ULTDH is significantly better, compared to LTDH, in terms of both costs and primary energy demand for a theoretical case representing a typical small Danish DH network. In the study, DH is produced by a combination of a 


\begin{tabular}{|c|c|c|}
\hline & LTDH & ULTDH \\
\hline Definition & $\begin{array}{l}\text { Higher temperature of supply } \\
\text { stream than required for direct } \\
\text { heat exchange to heat demand }\end{array}$ & $\begin{array}{l}\text { Lower temperature of supply } \\
\text { stream than required for direct } \\
\text { heat exchange to heat demand }\end{array}$ \\
\hline Temperatures & $\begin{array}{l}\text { Supply: e.g., } 55^{\circ} \mathrm{C} \text { to } 75{ }^{\circ} \mathrm{C} \\
\text { Return: e.g., } 25^{\circ} \mathrm{C} \text { to } 40^{\circ} \mathrm{C}\end{array}$ & $\begin{array}{l}\text { Supply: e.g., } 35{ }^{\circ} \mathrm{C} \text { to } 50{ }^{\circ} \mathrm{C} \\
\text { Return: e.g., } 20{ }^{\circ} \mathrm{C} \text { to } 35{ }^{\circ} \mathrm{C}\end{array}$ \\
\hline Carrier & \multicolumn{2}{|c|}{ Water based brine in closed loop (sensible heat) } \\
\hline Space heating & \multicolumn{2}{|c|}{ Floor heating or low-temperature radiators in secondary system } \\
\hline Hot water production & $\begin{array}{l}\text { Efficient local heat exchanger } \\
\text { heating DHW. }\end{array}$ & $\begin{array}{l}\text { Heat pump (or electric heater) } \\
\text { increases temperature to requi- } \\
\text { red level by utilising DH as } \\
\text { heat source (other sources possible) }\end{array}$ \\
\hline
\end{tabular}

Table 1: Definitions of LTDH and ULTDH in the current work

$45 \mathrm{HP}$ and a peak boiler of fixed input capacities, meaning that the output varies with boiler efficiency or HP Coefficient of Performance (COP). For HPs, COP is calculated based on temperatures according to a fixed Lorenz efficiency, which results in high COP, and thus high heat capacity, for ULTDH compared to LTDH. Another difference between the two studies is that the latter did not consider the changed flow requirements of the network.

In the present study, we focus on newly designed urban systems with low SH heat demands. The purpose is to assess, to which extent it is possible to obtain a performance benefit by utilising ULTDH with booster HPs, compared to LTDH. The performance was evaluated for two representative utility technologies which are used/proposed for production of DH in Nordic countries. The paper focuses on performance of utility supply and technical feasibility. The paper further addresses a method to obtain the optimal return emperature for ULTDH based on external parameters of the system.

Other applications of such systems include newly built island systems (outside conventional DH areas), or to replace individual heating solutions, both of which may present the possibility to connect to a LTDH transmission network later on.

\section{Methods}

The used definitions for LTDH and ULTDH are presented in Table 1. For ULTDH the installation at the end consumer includes both electrical HP boosters and heat exchangers, whereas for LTDH, the installation is comparable to those known from traditional DH networks, only with improved heat exchange performance. These installations are further addressed in sections 2.1 and 2.2, while the characteristics of the network is adressed in section 2.3. Two possible central heat production technologies for the DH

65 network were considered, namely a Combined Heat and Power plant (CHP) and central HPs. The utility technologies are further described in sections 2.4 and 2.5 .

Thermodynamic models of the considered technologies were developed and used in order to analyse their performance at reduced supply and return temperatures. The models were implemented in EES (Engineering Equation Solver) [14]. In section 2.6 the Coefficient of System Performance (COSP) is introduced as a performance indicator for the system as a whole. This was used to compare results of the individual networks.

\subsection{LTDH integration in multifamily buildings}

In modern energy efficient multifamily buildings, the heat demands are often divided into space heating (SH) and domestic hot water (DHW) (e.g., [8] and [15]). However, from a thermodynamic point of view, 


\begin{tabular}{lcc}
\hline Type & unit & value \\
\hline Yearly average heat demand of SH and DHW & MW & 1 \\
Pinch temperature difference SH HEX & $\mathrm{K}$ & 2.5 \\
Pinch temperature difference DHW and DHWC HEX & $\mathrm{K}$ & 5 \\
& & \\
Temperature DHW inlet & ${ }^{\circ} \mathrm{C}$ & 10 \\
Temperature DHW outlet $\left(T_{\mathrm{DHW}}\right)$ & ${ }^{\circ} \mathrm{C}$ & 55 \\
Temperature DHWC inlet & ${ }^{\circ} \mathrm{C}$ & $\left(T_{\mathrm{DHW}}-5\right)$ \\
Temperature DHWC outlet & ${ }^{\circ} \mathrm{C}$ & $\left(T_{\mathrm{DHW}}\right)$ \\
Temperature SH in room $\left(T_{\mathrm{SH}}\right)$ & ${ }^{\circ} \mathrm{C}$ & 20 \\
& & \\
SH share of heat demand $\left(f_{\mathrm{SH}}\right)$ & $\%$ & 50 \\
DHW share of heat demand $\left(f_{\mathrm{DHW}}\right)$ & $\%$ & 50 \\
DHWC share of DHW demand $\left(f_{\mathrm{DHWC}}\right)$ & $\%$ & 25 \\
\hline
\end{tabular}

Table 2: Assumptions used for SH, DHW and DHWC demands in reference case.

75 another heat demand should be included in the demand profile, due to its different temperature requirements. This demand is the DHW circulation (DHWC) losses, which typically occur from DHW pipes inside the heated perimeter (and thus reduces the SH demand), but results in a heat demand with high mean temperature. The slightly cooled DHW is returned to the DH installation by the circulation pump, and is then reheated to the set point temperature corresponding to DHW [16].

so An example of how this heat demand is addressed in multifamily buidings is presented in Fig. 1a, but many configurations and solutions are available [17]. Some solutions reheat the DHWC by mixing with DHW in stratified tanks, which requires the DHW to exceed the temperature levels required to avoid the bacteria growth. The annual heat demand for DHWC is typically small compared to DHW, but may actually in older buildings with poor DHW insulation exceed the DHW demand (e.g., [16] and [17]).

The LTDH system was modelled according to Fig. 1a, as three counter-flow heat exchangers with a fixed pinch temperature difference between $\mathrm{DH}$ and the heat demand, corresponding to given flow and temperature specifications on the secondary side. With decreasing supply temperatures, the DHWC demand becomes increasingly important in LTDH installations, as increased flow with high temperature is returned from the DHWC heat exchanger, which significantly increases the return temperature of the total installation.

As a reference case, table 2 presents the characteristics of the heat demands. The analysis focussed on the characteristic heat demands of modern low energy multi-story buildings, with high shares of DHW heat demand, compared to heat demand from SH. Similar temperatures and high shares for DHW are also reported for individual houses $[18,15]$. The DHWC share was considered relevant for newly build multifamily houses [17]. The share of SH and DHW were calculated as the individual demands compared to the total.

\subsection{ULTDH integration in multifamily buildings}

ULTDH utilizes booster units for the part of the end-consumer heat demand where the required temperature demand of the service is high. Such booster units are designed to enable the highest possible direct heat transfer between the DH and the service. As shown in Fig. 2, the booster units may be integrated on either primary or secondary side of the DH network [7]. By utilizing HPs for the booster service, the electricity consumption of supplying the remaining fraction is reduced compared to an electric heater. For the case where the heat source for the HP evaporator is supplied by the DH system, the DH return temperature may be lower than what is possible for direct heat exchange. This is key in order to obtain a high system performance when considering both utility plant, network and consumers. By controlling the return temperature from the booster unit, an additional degree of freedom is obtained in the network, which can be utilized to adjust the return temperature of an area to a range that is optimal for the entire system. In this way it is possible to adjust HP performance, pressure losses and heat losses from a network, and thus obtain a performance improvement. 


\begin{tabular}{lcc}
\hline Type & unit & value \\
\hline Yearly average heat loss $\left(\dot{Q}_{\text {DH,loss,dim }}\right)$ & $\%$ & 10 \\
Yearly average permissible specific pressure drop & $\mathrm{Pa} / \mathrm{m}$ & 50 \\
DH supply temperature & ${ }^{\circ} \mathrm{C}$ & 70 \\
DH return temperature & ${ }^{\circ} \mathrm{C}$ & 40 \\
Average temperature of soil & ${ }^{\circ} \mathrm{C}$ & 8 \\
Pump efficiency & $(-)$ & 0.9 \\
Pump motor efficiency & $(-)$ & 0.95 \\
\hline
\end{tabular}

Table 3: Assumptions used for calculation of heat losses and pump work in DH network.

For ULTDH systems, few solutions have been developed (e.g., [9]), which until now are mainly for single family dwellings. Newly developed units utilise two small booster HPs (see Fig. 1b) in order to match the temperature requirements of the heat demand profile of multifamily buildings. Both HPs are single stage units, which are scalable to match the demand. The design of the building installation for ULTDH, as well as the mathematical model, resembles the one for LTDH except for the integration of booster HPs. The calculation of the HP cycle, as well as the integration with sink and source, is further adressed in section 2.5 .

\subsection{DH network}

In Denmark, the heat losses for distribution grids range from $5 \%$ to $50 \%$ depending on many factors such as commissioning year, heat demand densities and temperatures [19]. For regular and large networks heat losses are in all cases below $25 \%$. All networks with heat losses above $25 \%$ supply less than $100 \mathrm{GWh}$ annually. The heat losses correspond to network operation supply temperatures during winter of $65{ }^{\circ} \mathrm{C}$ to $100{ }^{\circ} \mathrm{C}$.

For newly designed systems the heat losses are typically in the lower end of the range. It was estimated that for a reference system with supply and return temperatures of $70{ }^{\circ} \mathrm{C}$ and $40{ }^{\circ} \mathrm{C}$, respectively, distribution heat losses were $10 \%$ for an average hourly demand in the heating season.

The heat transfer characteristics for each pipe in the specific heat network was found, according to generalized models $[20,21]$. Based on these models, the dimensioning length and pipe sizes, as well as the temperature of supply and return at the consumer site, were found. The temperature of the soil was estimated as the average of the yearly temperature of the area $\left(8^{\circ} \mathrm{C}\right) . \mathrm{DH}$ networks are typically dimensioned according to a permissible specific pressure drop in the range $50 \mathrm{~Pa}$ to $100 \mathrm{~Pa}$ per meter for the coldest day (dimensioning at e.g., $-12{ }^{\circ} \mathrm{C}$ ) [22]. As the analysis was performed for a yearly average, the lower value of the permissible specific pressure drop $50 \mathrm{~Pa}$ per meter was used in this study.

A schematic figure of the supply side model elements is presented in Fig. 3. Besides the heat supply (extraction CHP plant or central HP), the pump work and the heat losses were calculated for both supply and return. Assumptions regarding pump work and heat losses are presented in Table 3

\subsection{Heat supply from extraction $C H P$}

The applied model of extraction type steam turbine (Rankine) cycles is based on data for two identical units (Avedøreværket Unit 1 and Amagerværket Unit 3) located in the Copenhagen area. The model follows the instructions of the proposal for simulator contest of ECOS 2003 [23, 24], where specific information about the temperatures, isentropic efficiencies, temperature differences, auxiliary power consumption and pressure losses are defined. A process flow sheet for the power cycle is presented in Fig. 4.

The model used for this analysis corresponded closely to the one used in $[25,7]$. The steam enters the intermediate (IP2) and low pressure part (LP1 + LP2) of the turbine train after expansion in the preceding turbine (IP1), and may be used for power generation or to supply district heating. The output of each product is controlled by adjusting the valves before the low pressure turbines and the district heating heat exchangers. 
Besides energy, entropy and mass balances, different, representative expressions were used to establish the impulse balances in different parts of the systems.

For each section of the modelled turbines, a turbine constant accounts for the swallowing capacity of a specific unit:

$$
C_{\text {tur }}=\frac{\dot{m} \cdot \sqrt{T_{\mathrm{in}}}}{\sqrt{p_{\mathrm{in}}^{2}-p_{\text {out }}^{2}}}
$$

where the mass flow of steam $\dot{m}$, the inlet temperature $T_{\text {in }}$ and pressures at inlet $p_{\text {in }}$ and outlet $p_{\text {out }}$ are used. Once installed, the swallowing capacity should be considered constant throughout the lifetime of the unit. The constant is applied to calculate the off-design operation of such units correctly.

For each of the valves, a flow coefficient was fixed, in order to account for the pressure losses when the valve is operated between fully open and fully closed. The constant is applied to calculate the off-design operation of the valves.

$$
\dot{V}=\alpha_{\text {valve }} \cdot k \cdot \sqrt{\frac{\Delta p_{\text {valve }}}{\rho_{\text {in }}}},
$$

where $\alpha$ is the flow coefficient, $k$ is the opening degree of the valve, $\rho_{\text {in }}$ is the density of the fluid at the inlet, and $\Delta p_{\text {valve }}$ is the pressure loss over the valve.

Considering DH temperatures of $100{ }^{\circ} \mathrm{C}$ and $50{ }^{\circ} \mathrm{C}$ for forward and return temperatures, the model represents a plant with an electric efficiency of $42.0 \%$ at full boiler load in condensing mode and $34.9 \%$ at full back-pressure mode, respectively. In full back-pressure mode the total energy utilization is $91.5 \%$.

\subsection{Performance of HPs for finite energy reservoirs}

A schematic diagram of a single stage vapour compression heat pump is presented in Fig. 5 similar to the one used in previous studies, e.g. [25, 26, 27]. The operating conditions of a heat pump can be evaluated based on six parameters: The temperature of the sink process stream $(\mathrm{DH})$ leaving the condenser $T_{\text {sink }}$, the temperature of the source entering the evaporator $T_{\text {source }}$, the process stream temperature glides from inlet to outlet in both heat exchangers $\left(\Delta T_{\text {sink }}\right.$ and $\left.\Delta T_{\text {source }}\right)$, and expressions defining the heat transfer capacity of the two heat exchangers, in this case the minimum temperature differences, $\Delta T_{\text {pinch, cond }}$ and $\Delta T_{\text {pinch, evap }}$. The pinch temperature difference, $\Delta T_{\text {pinch }}$ which may appear once or twice in both condenser and evaporator.

By these six temperature variables, all state points of the cycle were found by using property data of sink, source and heat pump working fluids (according to Table 4). An example of a the heat exchange processes for a pure refrigerant is presented in Fig. 6 .

The performance of the HPs were calculated based on the thermodynamic cycle, corresponding to the temperatures of heat sink and heat source, and a few basic assumptions for component performance. For the central HPs utilised for heat supply in the network the assumptions are listed in table 4 . For the booster heat pumps the assumptions are listed in table $5[9]$.

\subsection{Evaluation of system performance}

By utilising HPs in combination with CHP, it is not sufficient to determine the performance of the HP. The booster HPs may provide heat at a high COP, but consumes power produced at the CHP, and accordingly impacts the total system performance. Instead, a performance indicator based on the complete system is needed. The Coefficient of System Performance (COSP) (Eq. 3) was used to evaluate the complete supply scheme of a specific system. It includes all the various requirements for supplying the heat demand, as specified in table 2, and supplied by the network according to Fig. 3. 


\begin{tabular}{lcc}
\hline Type & unit & value \\
\hline Refrigerant & & R717 \\
Pinch temperature difference of HEX & $\mathrm{K}$ & 5 \\
Superheat after evaporation & $\mathrm{K}$ & 5 \\
Compressor isentropic efficiency (open type) & $(-)$ & 0.8 \\
Compressor motor efficiency & $(-)$ & 0.95 \\
Temperature heat source inlet & ${ }^{\circ} \mathrm{C}$ & 20 \\
Temperature heat source outlet & ${ }^{\circ} \mathrm{C}$ & 10 \\
\hline
\end{tabular}

Table 4: Assumptions used for central HP operating as heat supply for LTDH and ULTDH

\begin{tabular}{lcc}
\hline Type & unit & value \\
\hline Refrigerant & & R134a \\
Pinch temperature difference of HEX & $\mathrm{K}$ & 5 \\
Superheat after evaporation & $\mathrm{K}$ & 5 \\
Compressor isentropic efficiency incl. motor $\left(\eta_{\text {is,Booster }}\right)$ & $(-)$ & 0.7 \\
\hline
\end{tabular}

Table 5: Assumptions used for booster HPs for ULTDH

$$
\begin{aligned}
\operatorname{COSP}_{\text {demand }, \text { elec }} & =\frac{\dot{Q}_{\text {HeatSupply }}+\sum \dot{Q}_{\text {BoosterHP }}-\dot{Q}_{\text {DH,loss }}}{\dot{W}_{\text {HeatSupply }}+\sum \dot{W}_{\text {BoosterHP }}+\dot{W}_{\text {Pump }}} \\
& =\frac{\dot{Q}_{\text {Demand }}}{\sum \dot{W}}
\end{aligned}
$$

where $\dot{Q}_{\text {HeatSupply }}$ is the heat supplied by extraction CHP or central HP. The magnitude of the heat flow is influenced by the heat demand $\dot{Q}_{\text {Demand }}$ and the heat loss $\dot{Q}_{\mathrm{DH}, \text { loss }}$, as well as the amount of heat supplied

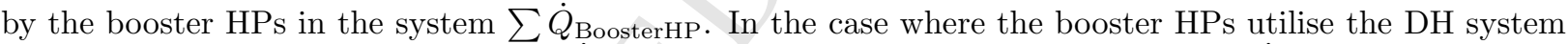
as the heat source, the heat supply $\sum \dot{Q}_{\text {BoosterHP }}$ and the electricity consumption $\sum \dot{W}_{\text {BoosterHP }}$ from such units are equal [25].

For the extraction CHP plant it was assumed, that the plant operates at full load in extraction mode by varying the extraction of steam from the IP turbines to the DH condensers. Based on this assumption, $\dot{W}_{\text {HeatSupply }}$ for the CHP can be calculated from the power loss factor by heat extraction $(\beta$-value) [28]. For the HP, the $\dot{W}_{\text {HeatSupply }}$ was found as the power consumption, related to the heat supply $\dot{Q}_{\text {HeatSupply }}$, by the COP of the HP.

\section{Results}

For each of the individual solutions considered, results were generated by variation of the temperatures in the DH network, which are the main operation parameters concerning the system performance. Variation in network temperatures (for LTDH) resulted in changes of the COSP of the system, as the pump work, DH network losses as well as performance of the central utility units change. Additionally, the load and the COP of the booster units of the ULTDH was found to be highly dependent on the network temperatures, which result in variations of power and $\mathrm{DH}$ consumption for boosting the high temperature demands.

For LTDH systems, the return temperature was derived as a result of the supply temperature, according to energy and mass balances for the direct heat exchange processes of $\mathrm{SH}$, DHW and DHWC, according to Fig. 1a. In this way certain supply temperatures result in high return temperatures, which not only affect the central utility production performance, but also significantly influences the pressure losses of the system, due to the higher mass flow needed to satisfy the demand. 
For the ULTDH systems, the return temperature of the substation depends on the direct heat exchange for SH and DHW demands, as well as the return temperature of the two booster HPs, which may be used as an optimisation parameter of the system. Results for ULTDH systems are thus presented as contour plots concerning both supply and return temperatures.

For each of the considered cases, similar parametric analyses were performed to investigate the influence of the various assumptions, and to assess the types of systems where the possible benefit of utilising the ULTDH systems were most significant.

\subsection{Performance of extraction CHP-unit at lowered DH temperatures}

For the extraction CHP unit, the influence of changed production temperatures was investigated for both LTDH and ULTDH.

In Fig. 7 three examples of the operational characteristcs at full boiler load are illustrated, showing how the extraction line of the plant changes with different network temperatures. The full grey colour represents operation at DH production between condensation operation $(0(\mathrm{MJ} / \mathrm{s}))$ and full back-pressure production (corresponding to $330(\mathrm{MJ} / \mathrm{s})$ ) for temperatures of supply at $100{ }^{\circ} \mathrm{C}$ and return at $50{ }^{\circ} \mathrm{C}$. Such operation corresponds to the design temperatures for the unit under consideration.

The two alternative extraction lines (in solid and dotted black colour) correspond to operation for supply at $80^{\circ} \mathrm{C}$ and return at $40^{\circ} \mathrm{C}$. Both lines are presented to emphasise the difference between off-design operation at lower temperatures than intended, or updated geometry of the turbines of the plant according to changing the design temperatures. For the solid black line, the turbine and valve coefficients were fixed according to $100{ }^{\circ} \mathrm{C}$ and return at $50{ }^{\circ} \mathrm{C}$ design, whereas the dotted line reflects the performance of a CHP-unit dimensioned for lower temperatures. The graph illustrates the improvement of the plant output at lower temperatures, and also illustrates remarkable changes in the characteristics, e.g., more noticeable no-loss points. For almost all cases of DH production, the unit with updated geometry showed an increase in power production. The difference between design and off-design operation of the CHP unit was found to be further increased at lower supply and return temperatures.

230 An example of the variation of the average $\beta$-value at changed temperatures is presented in Fig $8 \mathrm{a}$ and $8 \mathrm{~b}$ for a CHP unit with fixed turbine and valve coefficients according to $100{ }^{\circ} \mathrm{C}$ and return at $50{ }^{\circ} \mathrm{C}$ design. The average $\beta$-value was for each temperature set calculated as the difference of power production between condensation and full back-pressure operation.

For the LTDH temperature ranges presented in Table 1 (Fig. 8a), the $\beta$-value varies between $0.078(-)$ and $0.090(-)$. This corresponds to $\beta^{-1}$ values of 11.0 to $12.5(-)$, which indicates the heat generated by each unit of power sacrificed. The $\beta$-value is most sensitive to changes in the supply temperature (ratio $3: 1$ ).

For the corresponding ULTDH (Fig. 8b), the $\beta$-value was found to be between $0.070(-)$ ad $0.075(-)$. In this case, the $\beta$-value is more equally sensitive to changes in supply and return temeperature (ratio $2: 1$ ).

In case of turbine and valve coefficients in accordance with an updated design, the $\beta$-values were found to be further reduced. In the following sections, results for extraction CHP corresponds to fixed design coefficients at $100{ }^{\circ} \mathrm{C}$ supply and $50{ }^{\circ} \mathrm{C}$ return, unless further addressed.

\subsection{Performance of heat delivery for $L T D H$}

In Fig. 9a and 9b the performance of LTDH supply is presented in terms of COSP (black colour) for production based on extraction CHP and HP individually. For both cases, it was found that the COSP of the combined DH system increases with a reduction in supply temperatures below $80{ }^{\circ} \mathrm{C}$, and reaches optimum COSP corresponding to approximately $65{ }^{\circ} \mathrm{C}$ supply temperature. Further reduction in supply temperature resulted in reduction in COSP, which was mainly ascribed to a significant increase in pump work due to the given low difference between supply and return temperatures. The return temperature at the utility plant is presented in Fig. $9 \mathrm{a}$ and $9 \mathrm{~b}$ as a grey curve. For decreasing supply temperature, an increase of the return temperature was found, which is a result of the mass and energy balances of direct heat exchange for LTDH installations.

For DH production supplied by the extraction CHP unit, the optimum COSP was found to be approximately $10.6(-)$ at a supply temperature of $66{ }^{\circ} \mathrm{C}$. For the corresponding central HP, the optimum was found 
at slightly lower supply temperatures $\left(63{ }^{\circ} \mathrm{C}\right)$ with COSP of just below $3.7(-)$. The COP of the central HP was found to be 4.1 (-) for this specific operation temperature set. The optimal supply temperature of the central HP was lower than for the extraction CHP, as the COP of the HP is significantly lower than the corresponding $\beta^{-1}$, which shifts the optimal operation towards an operation with higher power consumption for pumps, but with increased COP due to the decreased supply temperature.

For each of the case studies, a parametric analysis was performed, in order to investigate the influence of the various assumptions. For each of the considered parameter changes, the analysis show COSP and temperature trends similar to the ones showed in Fig. 9a and 9b. Hence, it is found that for a given set of parameters, an optimal COSP value exist with corresponding supply and return temperature exist. These optima for the central HP case are presented in Fig. 10b. For each of the sets of input parameters, the COSP of the LTDH network supplied by HP technology, was found to be in the range of $3.45(-)$ to 4.15 (-). The optimal supply temperature was found to be in the range of $62{ }^{\circ} \mathrm{C}$ to $64{ }^{\circ} \mathrm{C}$, except for the cases with changed temperature requirements for DHW, which has a high influence of the optimum supply temperature. The highest COSP was found for a system with neglected circulation heat demand and heat loss. This is obviously a theoretical case only.

The trends of the parametric analysis for extraction CHP followed the above description of the central HP quite closely, except for the reduction of DHWC, where the optimal temperature shifted significantly towards a lower supply temperature (see Fig. 10a). The COSP of the LTDH network supplied by extraction CHP technology, was found to be in the range of 9.9 (-) to $11.6(-)$

\subsection{Performance of heat delivery for ULTDH}

In Fig. 11a and 11b the performance of ULTDH supply is presented in terms of COSP, for production supplied by extraction CHP and HP individually. For both cases it was found, that the highest COSP of the system was experienced for return temperatures between $22{ }^{\circ} \mathrm{C}$ to $27{ }^{\circ} \mathrm{C}$. A further reduction of return temperature to $20{ }^{\circ} \mathrm{C}$ was found to decrease COSP by $10 \%$ to $20 \%$. Both considered cases further reveal an area of very low COSP for low supply temperatures and high return temperatures. This was mainly due to a significant increase in pump work, to a level where the network utilises more electricity for pumps, than what is requested by the costumers in terms of heat demands.

For the DH network supplied by extraction CHP units (Fig. 11a), the highest value of COSP was found for a supply temperature of $50{ }^{\circ} \mathrm{C}$, which is the maximum limit for ULTDH. Accordingly, ULTDH is not an advantage in connection with a central CHP. At a supply temperature of $36{ }^{\circ} \mathrm{C}$ and a return temperature of $22{ }^{\circ} \mathrm{C}$, a COSP of 5.6 (-) was found. For a supply temperature of $50{ }^{\circ} \mathrm{C}$ and a return temperature of 27 ${ }^{\circ} \mathrm{C}$, the COSP was found to be $8.6(-)$. Both are significantly lower values of COSP than what was found for LTDH in Fig. 9a.

For systems supplied by a central HP, an optimum in terms of COSP was found within the considered temperature ranges of ULTDH. The location of the optimum was at a supply temperature of $44{ }^{\circ} \mathrm{C}$ and 24 ${ }^{\circ} \mathrm{C}$ return temperature. The COSP at these operation temperatures was higher than $4.1(-)$ which was the maximum found for LTDH in Fig. 9b. At a supply temperature of $36{ }^{\circ} \mathrm{C}$ and a return temperature of 22 ${ }^{\circ} \mathrm{C}$, a COSP of 3.9 (-) was found. For a supply temperature of $50{ }^{\circ} \mathrm{C}$ and a return temperature of $25{ }^{\circ} \mathrm{C}$, a COSP of 4.1 (-) was found. All three values of COSP are higher than what was found for LTDH.

In both figures, a small area of infeasible solutions was found corresponding to a combination of low supply and return temperatures. The infeasible area is marked with gray colour in the plot. Operation at such temperature combinations of supply and return was not possible due to very low return temperature of the booster units, reaching levels below the freezing point of pure water. In such case, operation would require an anti-freeze additive to the fluid of the $\mathrm{DH}$ network, which was not considered further.

In Fig. 12, the temperatures of the return flow of the booster units are presented $\left(\right.$ in $\left.{ }^{\circ} \mathrm{C}\right)$, corresponding to the results for COSP. The previously presented infeasible area is again indicated in gray. Additionally, the contour of the highest COSP for central HP supply (from Fig. 11b) is presented to show the temperatures of the returned DH flow from the evaporator of the booster HPs.

This shows, that the solutions with the highest values of COSP was found to correspond to return temperatures of $23{ }^{\circ} \mathrm{C}$ to $30{ }^{\circ} \mathrm{C}$. Further, systems with a $\mathrm{DH}$ return temperature lower than approximately $23{ }^{\circ} \mathrm{C}$ show a significant decrease in the required heat source return temperature. 
In Fig. 13a and 13b a parametric analysis is presented, which is comparable to the one performed for LTDH systems. The presented parametric analysis is performed for systems with DH supply from a central HP. Due to the additional dimension required to locate the optimum, Fig. 13a presents the exact location in terms of supply and return temperatures, whereas Fig. 13b presents the obtained COSP, along with the supply temperature for the optimum.

Two of the solutions presented in Fig. 13a were constrained by the considered range of supply temperatures in ULTDH. This is the case for "Fixed $\Delta \mathrm{P}$ DH design", as well as a system with a low fraction of demand for DHW (25\%), where both were constrained by the lower end of the range of supply temperatures. In case of lower DHW demand, the solution is further constrained by low return temperature. The remaining analysed solutions were found to be located at similar supply and return temperatures. In terms of COSP, the solutions are in a range of $3.9(-)$ to $4.7(-)$, which in all cases are higher than the comparable reference system for $\mathrm{LTDH}$.

In Fig. 14a and 14b the analysed parameters for both LTDH and ULTDH systems are compared for both utility technologies. For the case of extraction CHP plants, presented in Fig. 14a, each of the analysed ULTDH systems present a decrease in COSP, compared to a similar system utilising LTDH technology. The decrease was found to be in the range of $10 \%$ to $27 \%$. For the systems with heat supply by a central $\mathrm{HP}$, presented in Fig. 14b, the results are opposite, as the ULTDH technology presents an increase in performance for each of the considered solutions. The increase is between $7 \%$ and $23 \%$.

For both of the considered utility technologies, it was found that the analysed systems with a low fraction of the demand for DHW (25\%) result in better performance increase for ULTDH than for the reference case. Similarly, solutions with high fractions of DHW $(75 \%)$ result in lower performance changes than for the reference. Increased performances by utilising ULTDH systems were also experienced for systems with a high reference heat loss in the distribution system.

For both utility technologies, the analysed systems with increased SH temperature result in lower performance for ULTDH than for the reference case. Further, the different rules for dimensioning of DH results in similar results as for the reference for both technologies, although with a significantly different set of operation temperatures according to Fig 13a.

\section{Discussion}

In the presented analysis the COSP was used to easily compare the different choices in utility components and variations in temperatures for specific heat demands. In most applications, the origin of the energy may further differentiate the solutions, as both electricity and heat may be correlated to the amount of primary resources used for production, e.g. as primary energy factors [29, 30]. Further detail of the performance of the processes may be obtained using exergy analysis [31], as performed in other literature on heat pumps for district heating (eg. [32]). A significant difference between the method for exergy analysis and the method utilised for the current paper is the detailed accounting for heat sources for the central heat pump, which was considered very close to ambient conditions - i.e. with very little physical exergy content.

When using a central HP to supply the DH system, the resulting COSPs were found to be in the range of 3.9 (-) to 4.2 (-) for equipment with realistic component efficiencies and effectiveness, when including the relevant parameters such as DH system pressure and heat losses. According to Fig. 14b this was found to be a performance increase of between $7 \%$ and $24 \%$ compared to LTDH (13\% for reference case), and for the reference case approximately $25 \%$ compared to $\mathrm{DH}$ with $80{ }^{\circ} \mathrm{C}$ according to Fig. 9b. According to Torekov et al. [3] the variable costs are typically approximately $25 \%$ of the socioeconomic cost, indicating that compared to $\mathrm{DH} 80^{\circ} \mathrm{C}$, up to $6.25 \%$ reduction in socioeconomic costs may be achieved by this solution. The analysis did not elaborate further on economic performance, mainly due to high uncertainty of inhouse installation differences between ULTDH and LTDH solutions, as well as different cost assumptions related to installation of DH piping with different sizes.

Due to the observed reduction in performance for CHP systems, the proposed technology may be relevant in new areas of cities, where waste heat from electricity production is not abundant, and where the average consumption of space heating is low. The technology is worse in terms of COSP, as the COP of booster 
HPs was significantly lower than corresponding performance change for the CHP plant ( $\beta$-value). For CHP ( $\beta$-value) would be further decreased.

The parametric analysis showed, that a low fraction of the demand for DHW $(25 \%)$ in ULTDH results in higher performance increase compared to LTDH, than for the reference case. This might indicate, that the ULTDH system is better tailored to the buildings with higher SH demands, in case the return temperature of the SH part may be kept low.

The analysis was based on the assumption of the booster heat pump to utilise ULTDH supply as the heat source. Thus, no external heat sources were utilized in the multifamily house installation. Alternative heat sources for the booster evaporator may be considered with potential performance benefits. This is however not further investigated in the current analysis due to a couple of reasons. Primarily, both DH and external heat sources are not easily integrated in one solution, due to the lack of high temperature heat sources located in immediate proximity of dwellings, and with such solution it is required to asses the risk of freezing of the water in the system when low temperature heat sources are utilised. Furthermore, the additional degree of freedom, which was utilised to obtain COSP improvements, would not be present in case where the ambient (or waste heat) was utilised as the heat source.

ULTDH with electrical heaters are mentioned as a possible cost reduction in Zvingilaite et al. [9], but with many benefits of the ULTDH system. Similar to a system with external heat sources for the booster HP, supplementary electrical heaters would not allow a further reduction (or increase if needed) in return temperatures than the one obtained by direct heat exchange, and thus possibly not achieve similar performance improvements as a system with DH as the heat source for HPs. Further more the COP of the electrical heater would not match the COP of the utility plant.

A benefit of the system is that it may easily adjust to changed operation e.g., high SH demand or no $\mathrm{SH}$ demand. This may be done by adjusting the return temperature of the HP evaporator, to obtain a temperature difference for the DH network, which is better adjusted to the central utility production and pump work. From a system perspective, COSP may be optimized by fixing set points of booster HPs corresponding to a minimal total electricity consumption of the network. It should however be noted, that for the user of the multifamily installation, the economically optimal return temperature is higher than that for the system, in case heat is cheaper than electricity. This is because COP of the booster heat pump will increase with increasing return temperature from the evaporator.

\section{Conclusion}

With a decrease in heat demands for space heating in newly built buildings, heat losses in distribution networks become increasingly important, as the total amount of delivered energy is significantly decreased.

In order to obtain performance improvement compared to LTDH networks, further reduction in supply temperatures (ULTDH) along with the use of booster HPs was evaluated.

The analysis was based on the assumption of booster HPs to utilise ULTDH supply as the heat source.

From a system perspective, the best performance, evaluated as COSP, may be achieved by utilisation of the additional degree of freedom, that originates from the choice of evaporation temperature of booster HPs. This allows the operator to control the return temperature of the network. In this way, increasing the temperature difference for the booster units, which reduces the COP of hot water preparation, may benefit the central DH production, pump work and heat losses in the network.

The analysis focussed on two cases, where the supply of heat for the network origins from either an extraction CHP plant or alternatively from a central DH HP.

It was possible to further reduce the temperatures of the DH networks, which in turn lead to a reduction in heat losses from the network. In networks supplied by CHP plants, the use of ULTDH and booster HPs decreases the COSP by approximately $20 \%$, compared to an optimised LTDH network, where heat may be transferred directly by heat exchangers. This is the result of higher electricity consumption of the booster units than the corresponding change at the CHP plant.

For heat supply by central HPs, a performance increase of $12 \%$ for the reference calculations case was found. Based on an analysis of the key parameters, it was found that the ULTDH provides a performance 
increase for all cases compared to the similar LTDH. The performance increase varied from $7 \%$ to $23 \%$. This is the case, as the marginal COP of booster HPs was found to be similar to that of the central HP, but it is only utilised for the part of the total demand related to hot water consumption.

\section{Acknowledgements}

This research project is financially funded by EUDP (Energy Technology Development and Demonstration). Project title: "EnergyLab Nordhavn - Smart components in integrated energy systems", project number: 64015-0055

\section{References}

[1] Münster, M., Morthorst, P.E., Larsen, H.V., Bregnbæk, L., Werling, J., Lindboe, H.H., et al. The role of district heating in the future Danish energy system. Energy 2012;48(1):47-55.

[2] Connolly, D., Lund, H., Mathiesen, B.V., Werner, S., Möller, B., Persson, U. et al. Heat roadmap Europe: Combining district heating with heat savings to decarbonise the EU energy system. Energy Policy 2014;65:475-489.

[3] Torekov, M., Bahnsen, N., Qvale, E.B. The relative competitive positions of the alternative means for domestic heating. Energy 2007;32(5):627-633.

[4] Persson, U., Werner, S. Heat distribution and the future competitiveness of district heating. Applied Energy $2011 ; 88(3): 568-576$.

5] Mathiesen, B., Lund, H., Connolly, D., Wenzel, H., Østergaard, P., Möller, B., et al. Smart energy systems for coherent $100 \%$ renewable energy and transport solutions. Applied Energy 2015;145:139 - 154.

[6] Lund, H., Werner, S., Wiltshire, R., Svendsen, S., Thorsen, J., Hvelplund, F., et al. 4th generation district heating $(4 \mathrm{GDH})$. Integrating smart thermal grids into future sustainable energy systems. Energy 2014;68:1-11.

[7] Ommen, T., Markussen, W., Elmegaard, B. Lowering district heating temperatures - Impact to system performance in current and future Danish energy scenarios. Energy 2016;94:273-291.

[8] Brand, M., Svendsen, S. Renewable-based low-temperature district heating for existing buildings in various stages of refurbishment. Energy 2013;62:311-319.

[9] Zvingilaite, E., Ommen, T., Elmegaard, B., Franck, M. Low Temperature District Heating Consumer Unit with Micro Heat Pump for Domestic Hot Water Preparation. District Energy Development Center; 2012, p. 136-143.

10] Yang, X., Li, H., Svendsen, S. Alternative solutions for inhibiting legionella in domestic hot water systems based on low-temperature district heating. Building Services Engineering Research and Technology 2016;37(4):468-478.

[11] Elmegaard, B., Ommen, T., Markussen, M., Iversen, J. Integration of space heating and hot water supply in low temperature district heating. Energy and Buildings 2016;124:255-264.

[12] Köfinger, M., Basciotti, D., Schmidt, R., Meissner, E., Doczekal, C., Giovannini, A. Low temperature district heating in Austria: Energetic, ecologic and economic comparison of four case studies. Energy 2015.

[13] Østergaard, P.A., Andersen, A.N.. Booster heat pumps and central heat pumps in district heating. Applied Energy 2016;184(15):1374-1388.

[14] F-Chart Software (LLC.), . Engineering equation solver (ees). 1992.

[15] Rosa, A.D., Christensen, J. Low-energy district heating in energy-efficient building areas. Energy 2011;36(12):6890-6899.

16] Bøhm, B., Danig, P.. Monitoring the energy consumption in a district heated apartment building in Copenhagen, with specific interest in the thermodynamic performance. Energy and Buildings 2004;36(3):229-236.

[17] Bøhm, B., Schrøder, F., Bergsøe, N.C.. Varmt Brugsvand - Måling af forbrug og varmetab fra cirkulationsledninger. 2009. ISBN 9788756313728.

[18] Brand, M., Rosa, A.D., Svendsen, S.. Energy-efficient and cost-effective in-house substations bypass for improving thermal and DHW (domestic hot water) comfort in bathrooms in low-energy buildings supplied by low-temperature district heating. Energy 2014;67:256-267.

[19] Dansk Fjernvarme. Benchmarking, statistics 2014/2015 [in Danish: Benchmarking, statistik 2014/2015]. 2015. URL: http://www.danskfjernvarme.dk/viden-om/aarsstatistik/benchmarking-statistik-2014-2015; [accessed 01.10.16].

[20] Kvisgaard, B., Hadvig, S. Heat loss from pipelines in district heating systems [in Danish: Varmetab fra fjernvarmeledninger]. Teknisk forlag; 1980. ISBN 8757106355, 9788757106350.

[21] Bøhm, B. Simple methods for determination of heat losses from district heating pipes under normal conditions [in Danish: Enkle metoder til bestemmelse af varmetab fra fjernvarmeledninger under normal drift]. Danmarks Tekniske Højskole, Lyngby (Denmark) and Sønderborg Fjernvarmeselskab A.m.b.A., Sønderborg (Denmark).; 1990. ISBN 8788038181, 9788788038187.

22] Rosa, A.D., Li, H., Svendsen, S.. Method for optimal design of pipes for low-energy district heating, with focus on heat losses. Energy 2011;36(5):2407 - 2418.

[23] Houbak, N. Proposal for simulator contest. Proceedings of the 16th International ECOS conference. Volume 1, 2, and 3; DTU, Technical University of Denmark; 2003.

[24] Elmegaard, B., Houbak, N. Simulaton of the Avedøreværket Unit 1 Cogeneration Plant with DNA. Proceedings of The 16th International Conference on Efficiency, Cost, Optimization, Simulation, and Environmental Impact of Energy Systems (ECOS 2003),; Technical University of Denmark; 2003. 
[25] Ommen, T., Markussen, W.B., Elmegaard, B. Heat pumps in combined heat and power systems. Energy 2014;76(0):9891000.

[26] Eisa, M.A.R., Best, R., Holland, F.A. Working fluids for high temperature heat pumps. Journal of Heat Recovery Systems 1986;6(4):305.

[27] Brunin, O., Feidt, M., Hivet, B. Comparison of the working domains of some compression heat pumps and a compressionabsorption heat pump. International Journal of Refrigeration 1997;20(5):308.

[28] Verbruggen, A. Combined heat and power (CHP) essentials. International Journal of Energy Technology and Policy 2007;5(1):1-16

[29] Wilby, M. R., Gonzlez, A.B.R., Daz, J. J. V. Empirical and dynamic primary energy factors, Energy 73 (2014) $771-779$.

[30] Schicktanz, M.,Wapler, J., Henning, H.-M. Primary energy and economic analysis of combined heating, cooling and power systems, Energy 36 (1) (2011) $575-585$.

[31] Bejan, A., Tsatsaronis, G., Moran, M. Thermal Design \& Optimization, 1st Edition, John Wiley \& Sons, New York, 1996. ISBN 9780471584674.

[32] Jensen, J.K., Ommen, T., W. B. Markussen, W.B.,Elmegaard, B. Design of serially connected district heating heat pumps utilising a geothermal heat source, Energy. 2017;xxx(1):1-13 


\section{List of Figures}

1 Example of current and future integration of LTDH and ULTDH in multifamily buildings . . 15

2 heat pump (or supplementary heater) configuration possibilities in a ULTDH system [7] . . . 16

Three main elements included in the model for supply of LT- or ULTDH to buildings. . . . . 17

4 Process flow sheet of the considered extraction CHP-plant. . . . . . . . . . . . . . 18

5 Schematic diagram of a single stage heat pump system . . . . . . . . . . . . . . . . . . 19

6 Schematic diagram of condenser and evaporator in a single stage heat pump system. The transferred heat is normalised for each of the heat exchangers . . . . . . . . . . . . . . 20

CHP characteristics of the extraction line at changed temperatures compared to the design

for both fixed and optimized turbine configuration. . . . . . . . . . . . . . . 21

$8 \beta$-value of extraction CHP for temperatures corresponding to LTDH and ULTDH . . . . . . . 22

9 COSP of LTDH solutions at for two different production technologies. . . . . . . . . . . . 23

10 Parametric analysis for LTDH supplied by central HP, corresponding to changed assumptions for heat demand and system constraints. . . . . . . . . . . . . . . . . . . . . . . . 24

11 COSP of ULTDH solutions at for two different production technologies . . . . . . . . . . . 25

12 Return temperature from the booster HP in an ULTDH system according to the results shown in Fig. 11a and 11b. The black oval curve indicates the optimum range for a system with central HP. . . . . . . . . . . . . . . . . . . . . . . . . . 26

13 Parametric analysis for ULTDH supplied by central HP, corresponding to changed assumptions for heat demand and system constraints. . . . . . . . . . . . . . . . . 27

14 Difference between COSP values of LTDH and ULTDH for various cases. . . . . . . . . . . . 28 


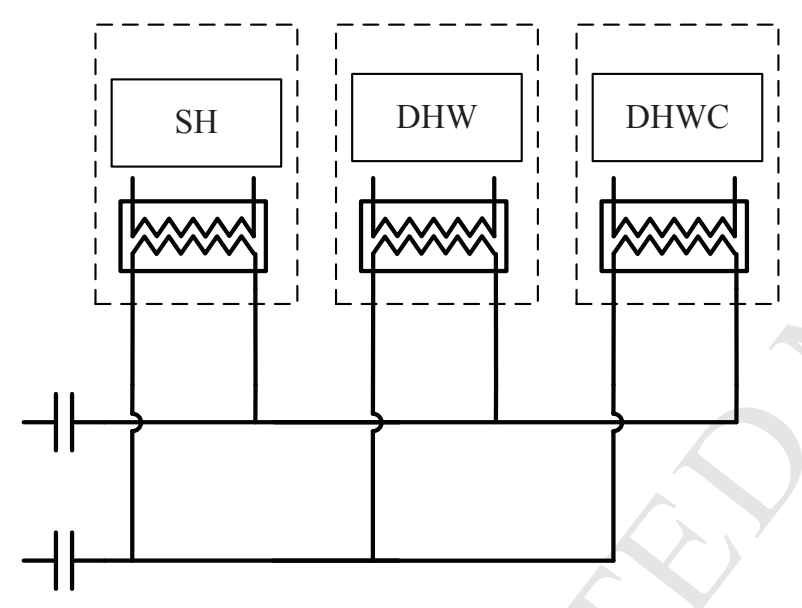

(a) LTDH in multifamily buildings

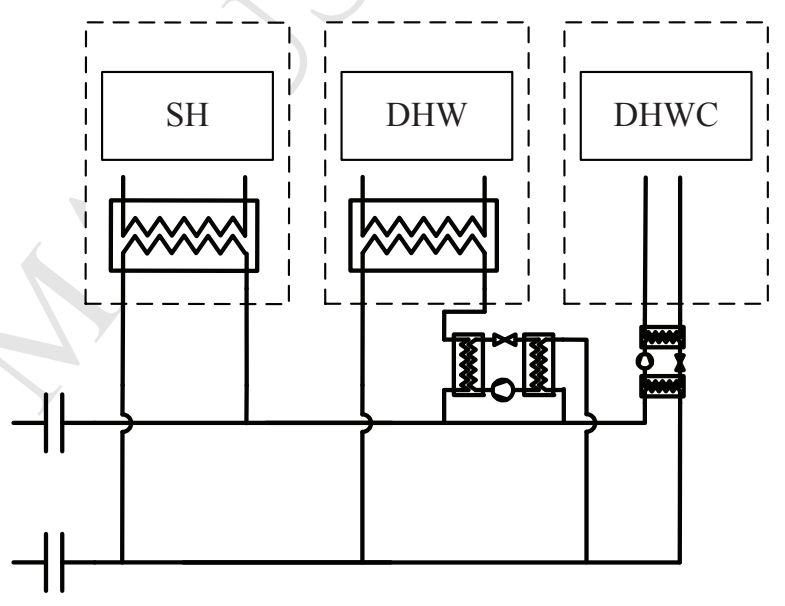

(b) ULTDH in multifamily buildings

Figure 1: Example of current and future integration of LTDH and ULTDH in multifamily buildings 


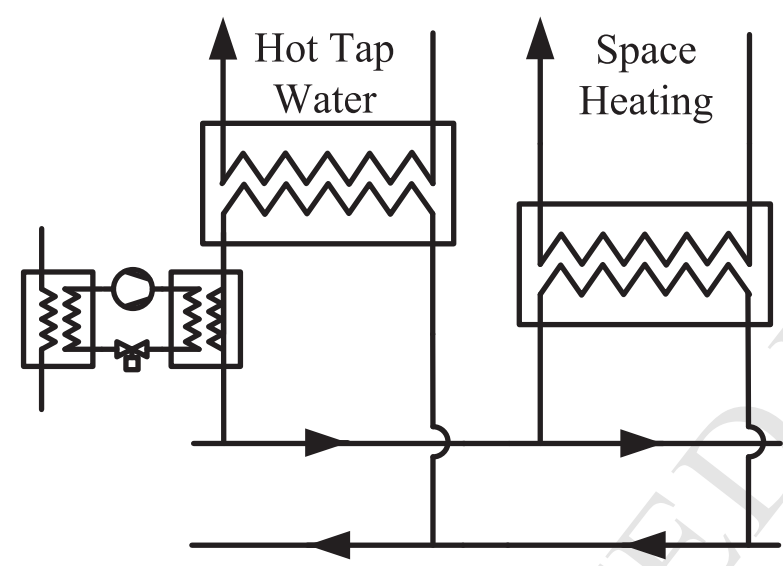

(a) Heat pump on primary side of the tap water heat exchanger.

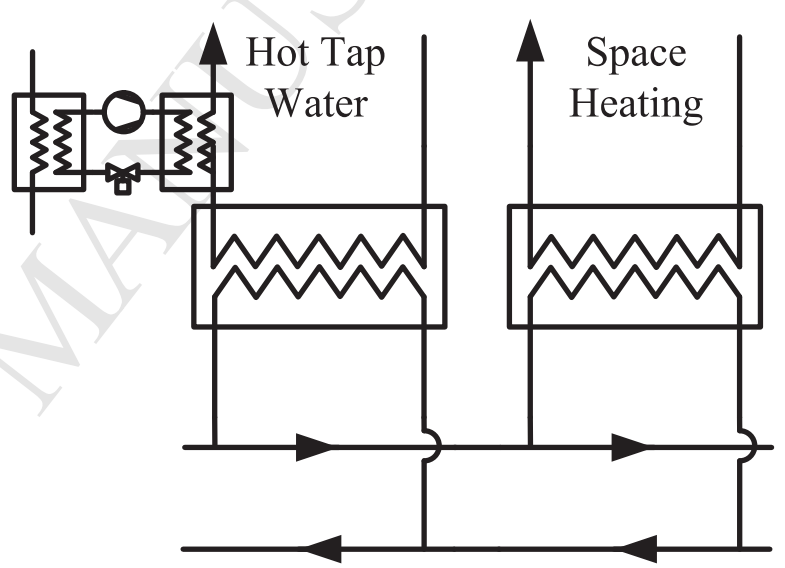

(b) Heat pump on secondary side of the tap water heat exchanger.

Figure 2: heat pump (or supplementary heater) configuration possibilities in a ULTDH system [7] 


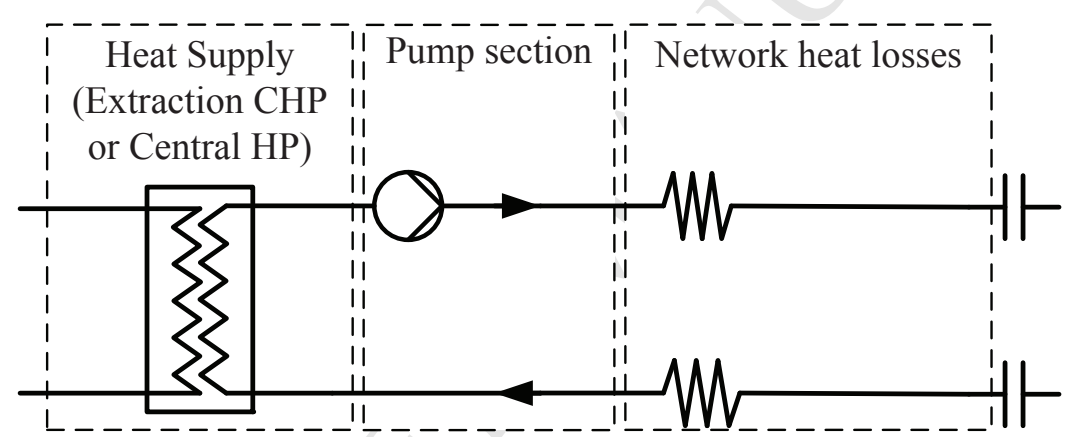

Figure 3: Three main elements included in the model for supply of LT- or ULTDH to buildings. 


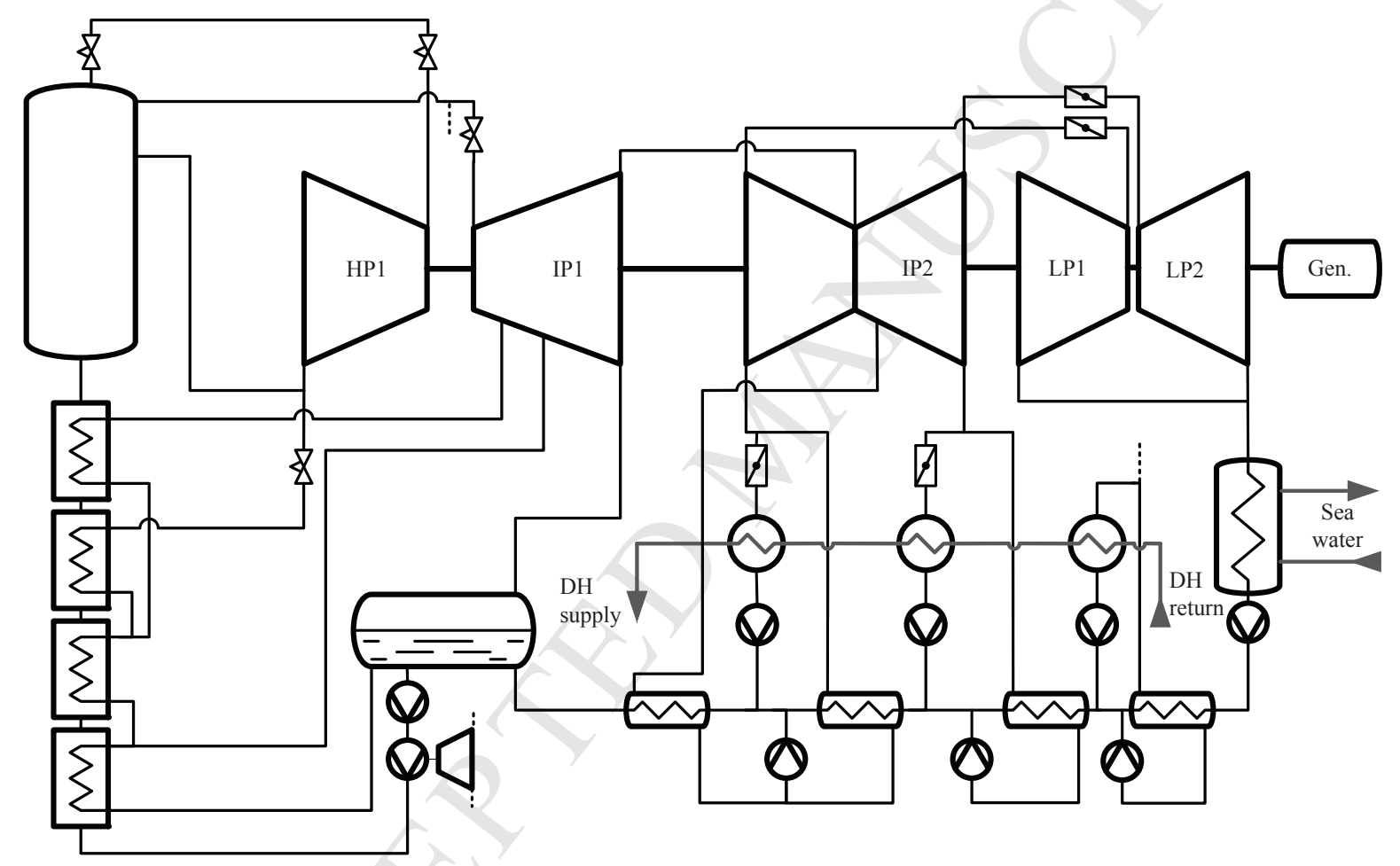

Figure 4: Process flow sheet of the considered extraction CHP-plant. 


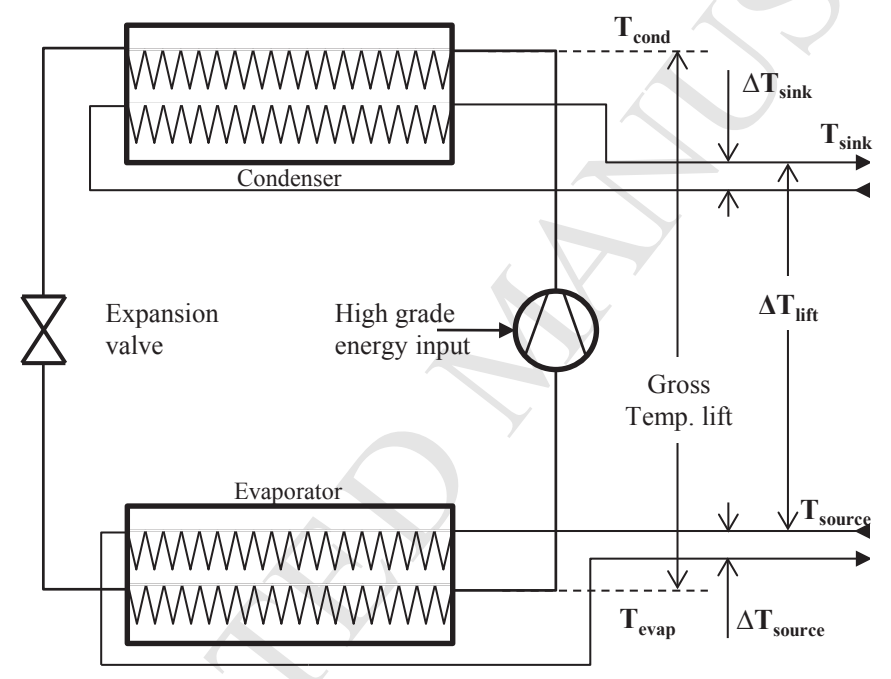

Figure 5: Schematic diagram of a single stage heat pump system 


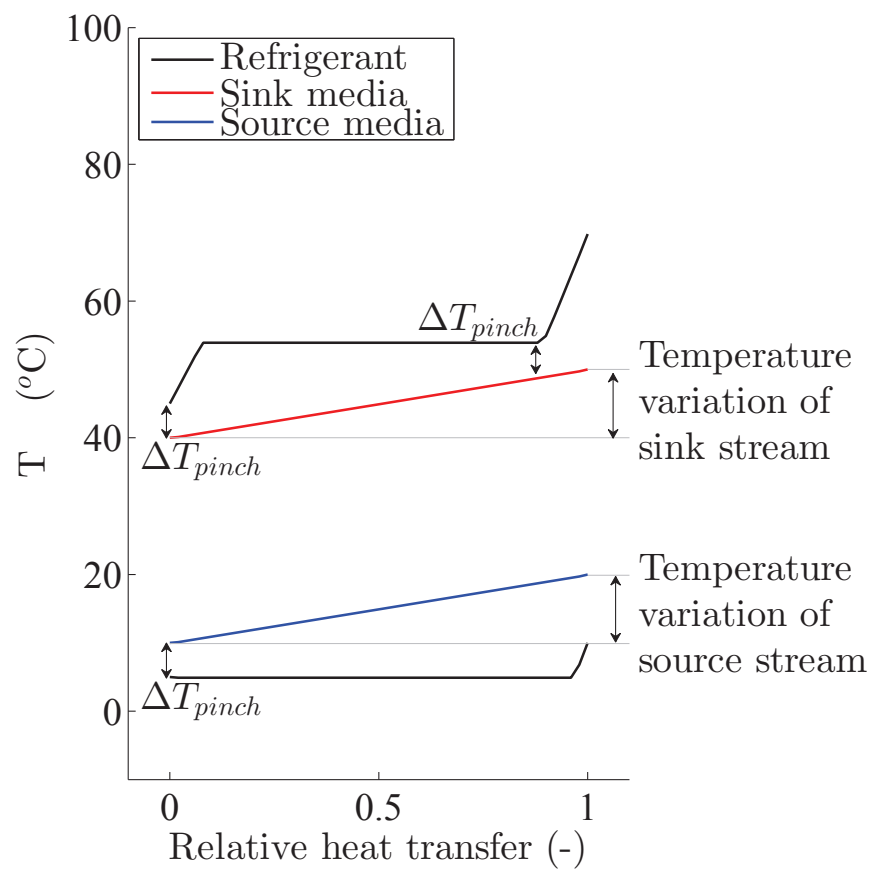

Figure 6: Schematic diagram of condenser and evaporator in a single stage heat pump system. The transferred heat is normalised for each of the heat exchangers 


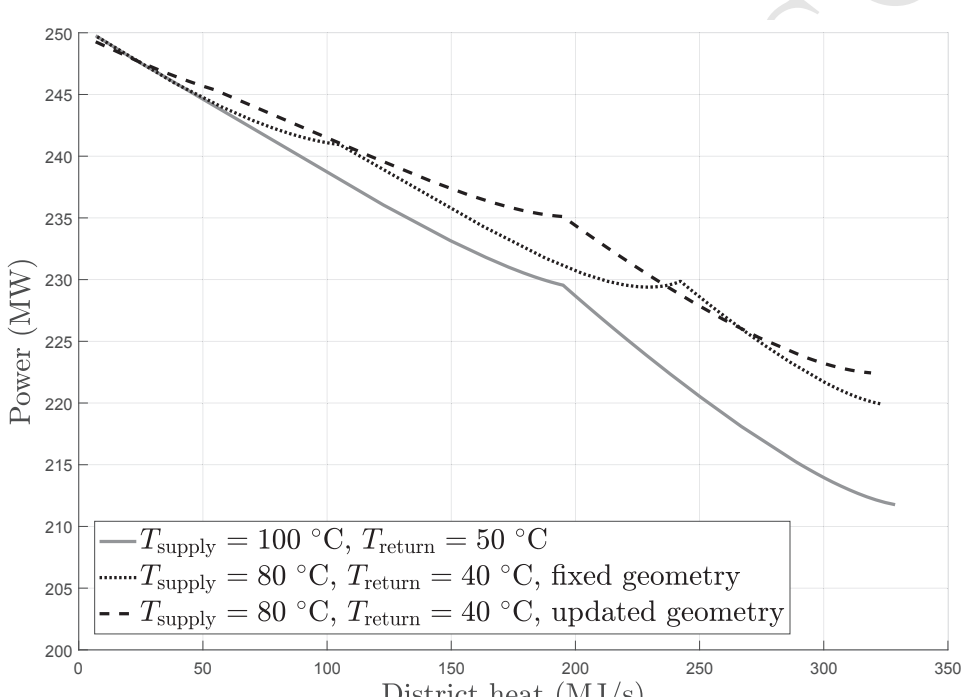

Figure 7: CHP characteristics of the extraction line at changed temperatures compared to the design for both fixed and optimized turbine configuration. 


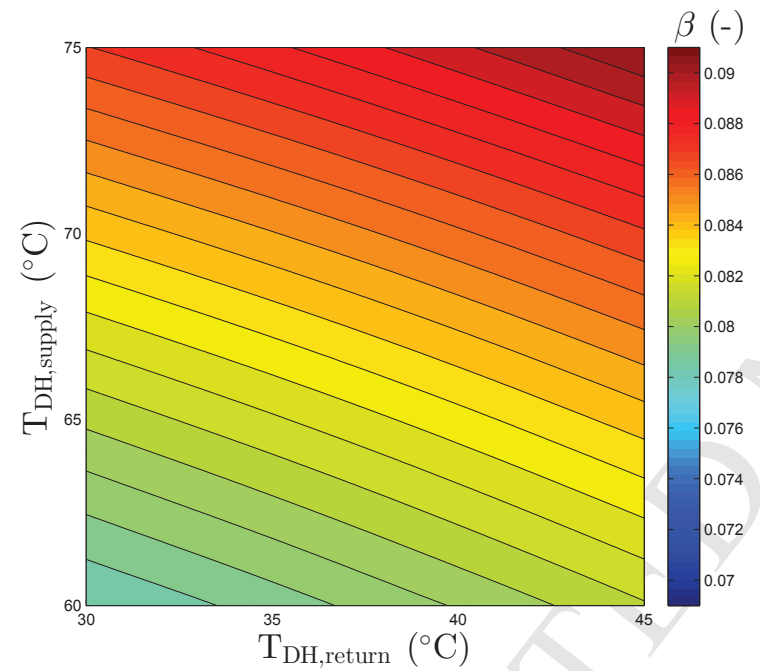

(a) Temperatures corresponding to LTDH

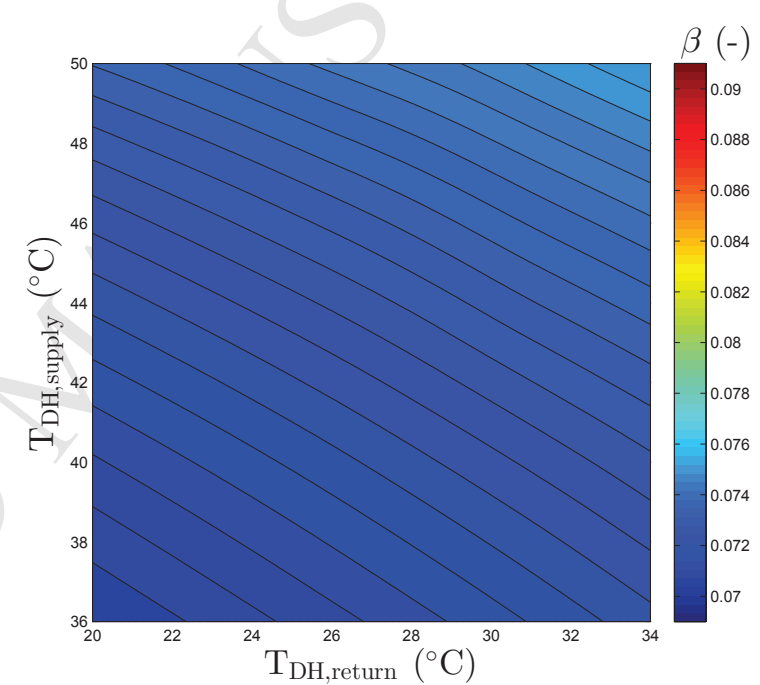

(b) Temperatures corresponding to ULTDH

Figure 8: $\beta$-value of extraction CHP for temperatures corresponding to LTDH and ULTDH 


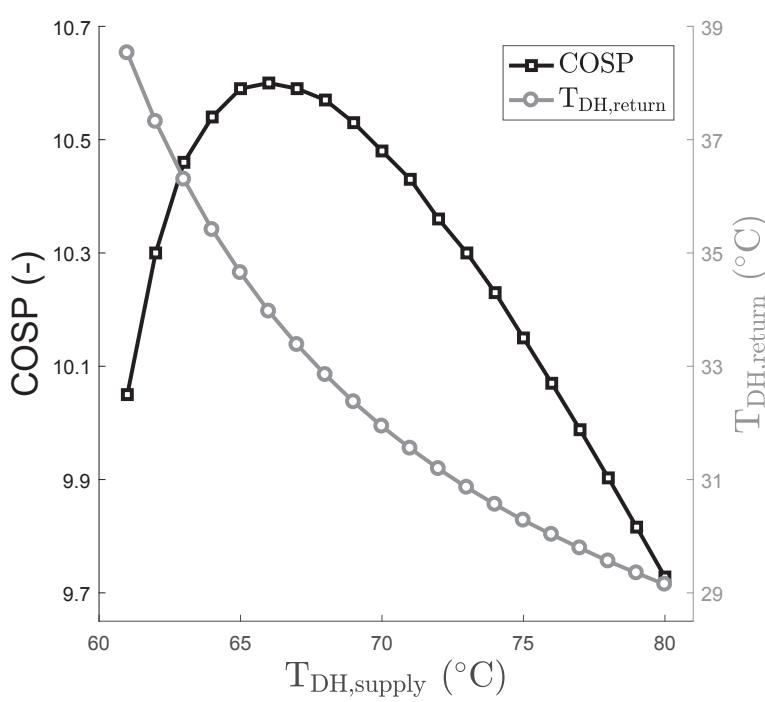

(a) LTDH supplied by extraction CHP

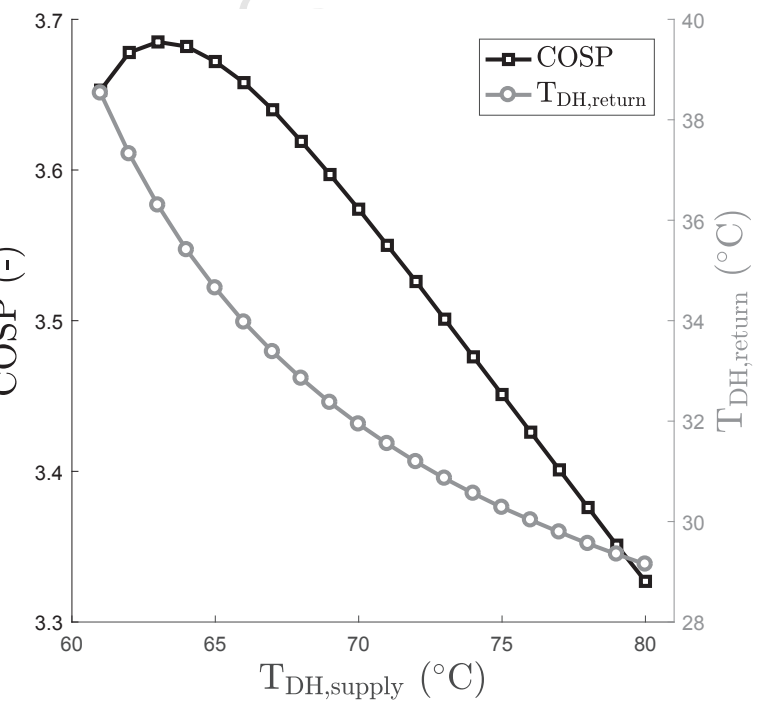

(b) LTDH supplied by central HP

Figure 9: COSP of LTDH solutions at for two different production technologies. 


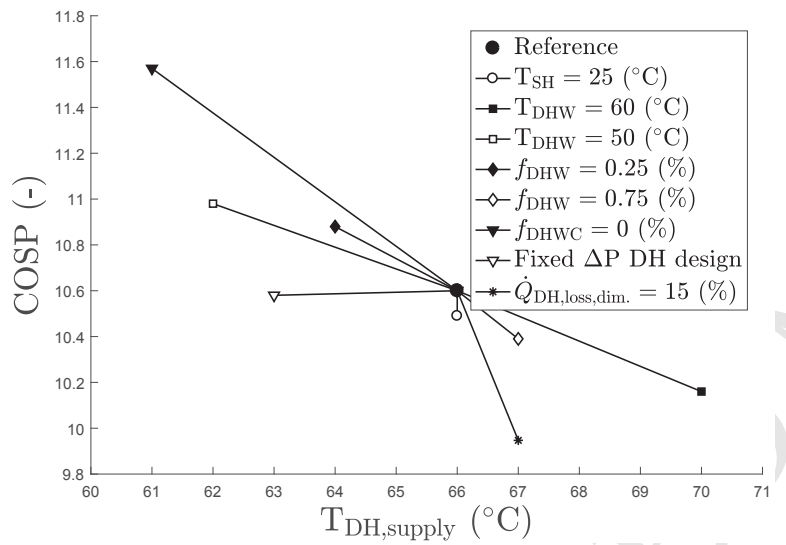

(a) LTDH supplied by extraction CHP

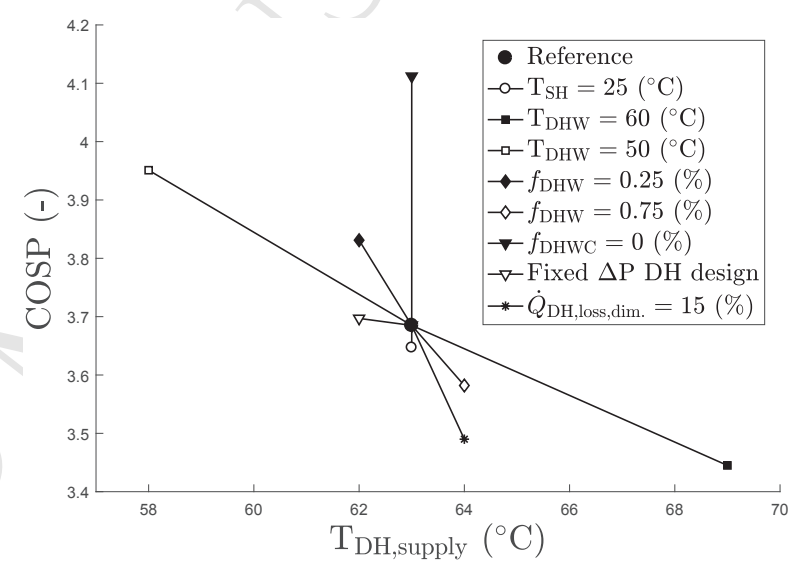

(b) LTDH supplied by central HP

Figure 10: Parametric analysis for LTDH supplied by central HP, corresponding to changed assumptions for heat demand and system constraints. 


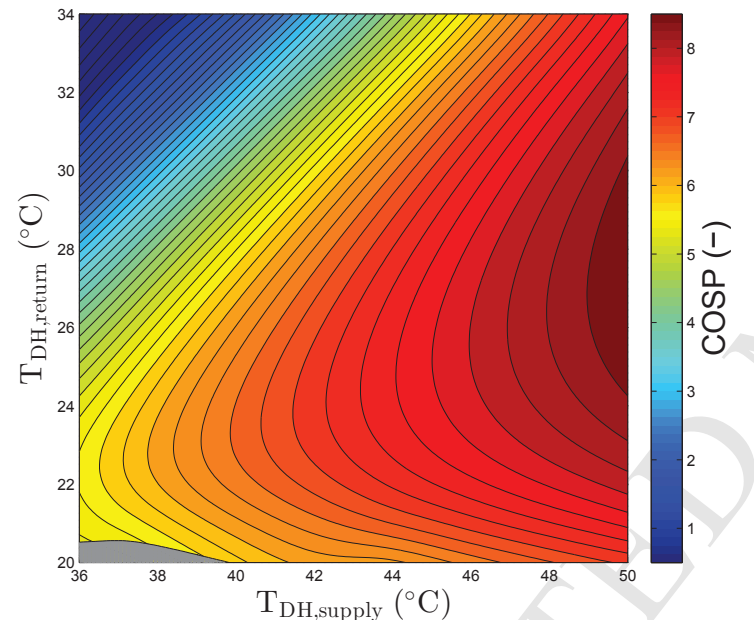

(a) ULTDH supplied by extraction CHP.

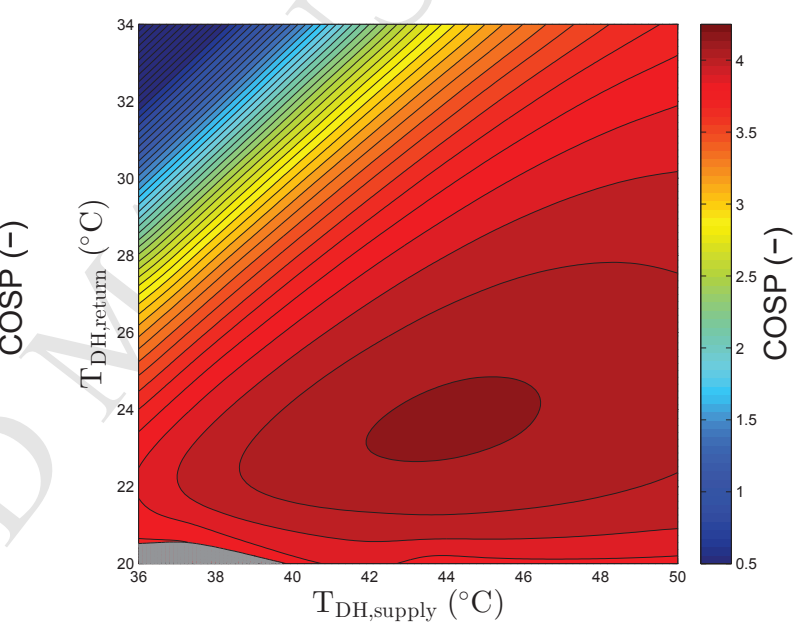

(b) ULTDH supplied by central HP.

Figure 11: COSP of ULTDH solutions at for two different production technologies 


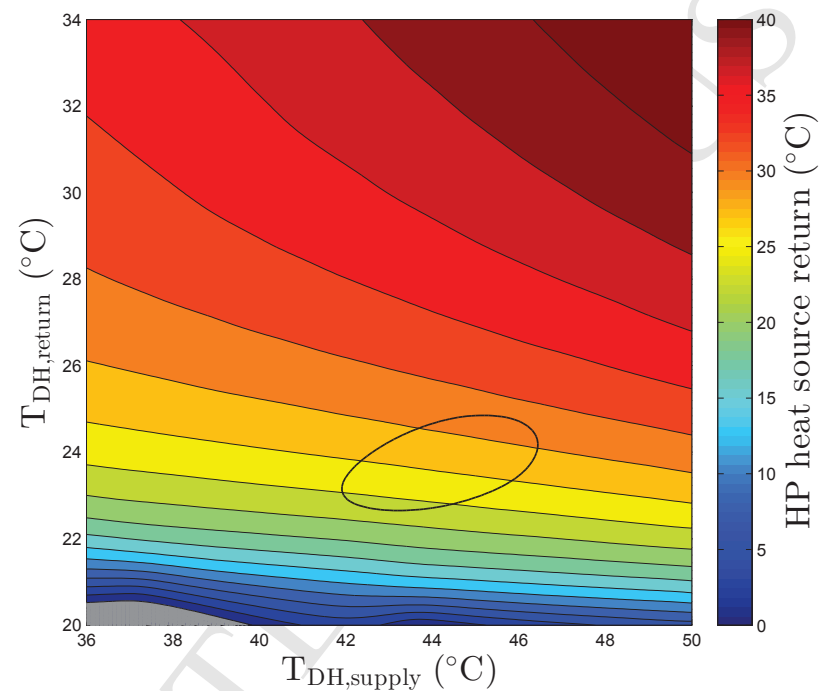

Figure 12: Return temperature from the booster HP in an ULTDH system according to the results shown in Fig. 11a and 11b. The black oval curve indicates the optimum range for a system with central HP. 


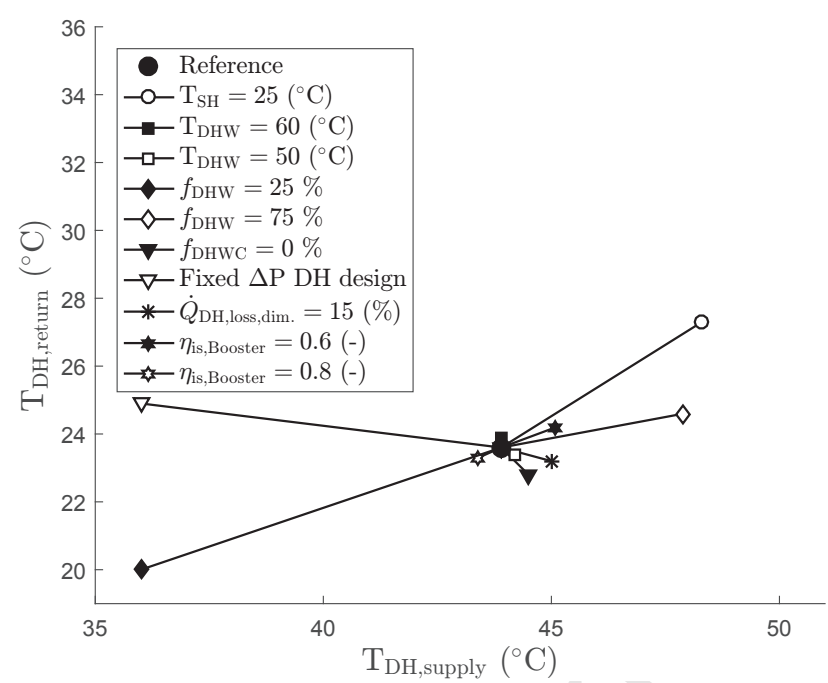

(a) Temperatures for optimum COSP.

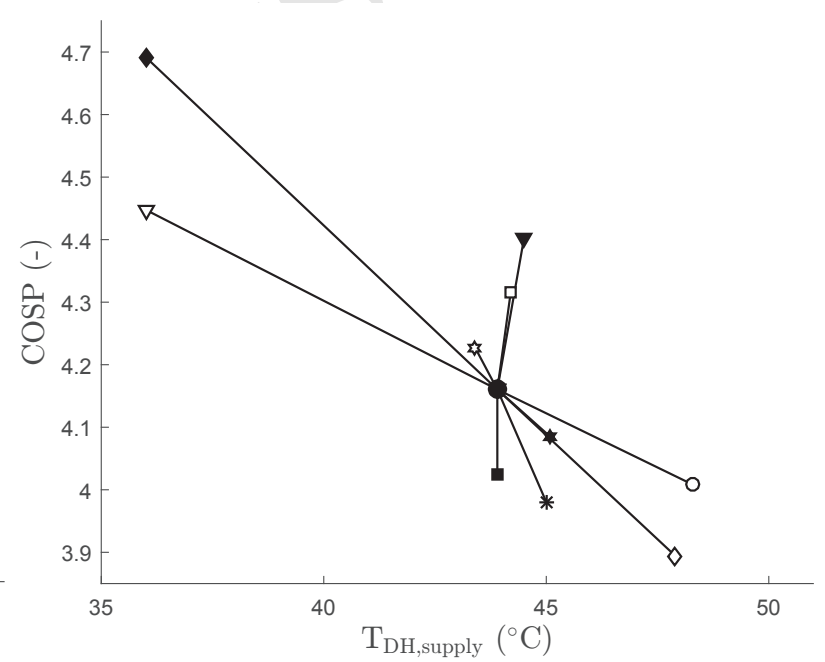

(b) Optimum COSP.

Figure 13: Parametric analysis for ULTDH supplied by central HP, corresponding to changed assumptions for heat demand and system constraints. 


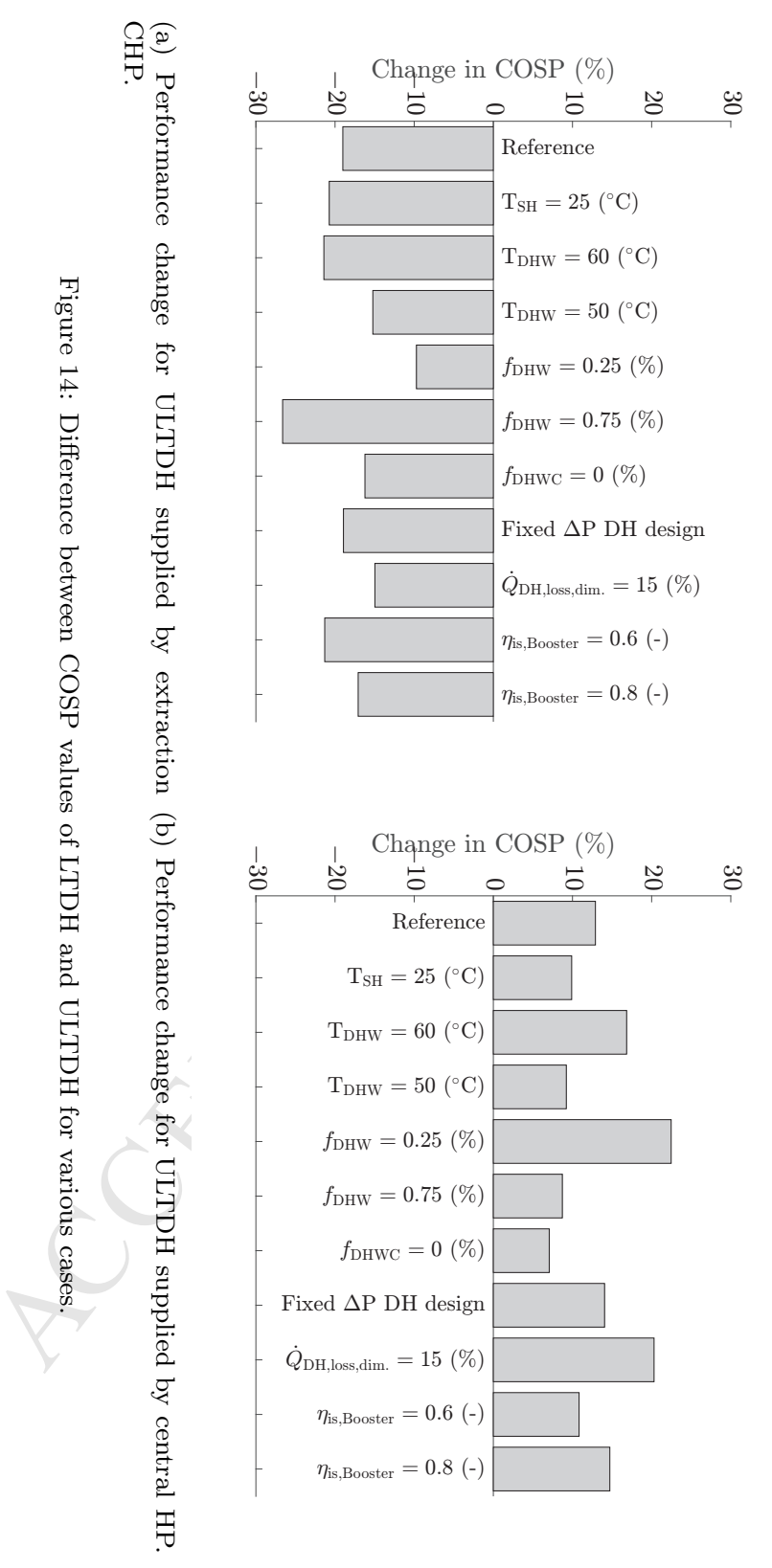


Highlights:

Performance of ultra low and low temperature district heating (DH) were analysed

For the analysis of ultra low temperature $\mathrm{DH}$, booster heat pumps (HPs) were proposed

Two central production technology cases were considered

Performance improvements of up to $12 \%$ were found for systems supplied by central HPs 